\title{
Ecosystem regimes and responses in a coupled ancient lake system from MIS $5 b$ to present: the diatom record of lakes Ohrid and Prespa
}

\author{
Aleksandra Cvetkoska ${ }^{1}$, Elena Jovanovska ${ }^{2}$, Alexander Francke ${ }^{3}$, Slavica Tofilovska ${ }^{4}$, Hendrik Vogel $^{5}$, \\ Zlatko Levkov ${ }^{4}$, Timme H. Donders ${ }^{1}$, Bernd Wagner ${ }^{3}$, and Friederike Wagner-Cremer ${ }^{1}$ \\ ${ }^{1}$ Utrecht University, Palaeoecology, Department of Physical Geography, Utrecht, the Netherlands \\ ${ }^{2}$ Justus Liebig University, Department of Animal Ecology and Systematics, Giessen, Germany \\ ${ }^{3}$ University of Cologne, Institute of Geology and Mineralogy, Cologne, Germany \\ ${ }^{4}$ University Ss Cyril and Methodius, Institute of Biology, Skopje, Macedonia \\ ${ }^{5}$ University of Bern, Institute of Geological Sciences \& Oeschger Centre for Climate Change Research, Bern, Switzerland
}

Correspondence to: Aleksandra Cvetkoska (acvetkoska@yahoo.com)

Received: 15 August 2015 - Published in Biogeosciences Discuss.: 11 September 2015

Revised: 30 April 2016 - Accepted: 12 May 2016 - Published: 31 May 2016

\begin{abstract}
We reconstruct the aquatic ecosystem interactions since the last interglacial period in the oldest, most diverse, hydrologically connected European lake system, by using palaeolimnological diatom and selected geochemistry data from Lake Ohrid "DEEP site" core and equivalent data from Lake Prespa core, Co1215. Driven by climate forcing, the lakes experienced two adaptive cycles during the last $92 \mathrm{ka}$ : "interglacial and interstadial" and "glacial" cycle. The shortterm ecosystems reorganizations, e.g. regime shifts within these cycles substantially differ between the lakes, as evident from the inferred amplitudes of variation. The deeper Lake Ohrid shifted between ultra oligo- and oligotrophic regimes in contrast to the much shallower Lake Prespa, which shifted from a deeper, (oligo-) mesotrophic to a shallower, eutrophic lake and vice versa. Due to the high level of ecosystem stability (e.g. trophic state, lake level), Lake Ohrid appears relatively resistant to external forcing, such as climate and environmental change. Recovering in a relatively short time from major climate change, Lake Prespa is a resilient ecosystem. At the DEEP site, the decoupling between the lakes' response to climate change is marked in the prolonged and gradual changes during the MIS 5/4 and 2/1 transitions. These response differences and the lakes' different physical and chemical properties may limit the influence of Lake Prespa on Lake Ohrid. Regime shifts of Lake Ohrid due to potential hydrological change in Lake Prespa are not evident in the
\end{abstract}

data presented here. Moreover, a complete collapse of the ecosystems functionality and loss of their diatom communities did not happen in either lake for the period presented in the study.

\section{Introduction}

The structure and functions of the continental ecosystems constantly changed throughout the Quaternary, driven by a series of successive climate variations at different temporal scales. As dynamic entities, the ecosystems developed through these fluctuations with a "panarchy", defined as a series of hierarchical adaptive cycles interacting across multiple scales of space and time (Holling, 2001; Delcourt and Delcourt, 2004; Allen et al., 2014). Four functional phases, controlled by top-down and bottom-up processes, have been identified within these cycles, growth $(r)$, conservation $(k)$, release $(\Omega)$, and reorganization $(\alpha)$. Change in the processes controlling the ecosystem's structure and functions can lead to regime change and creation of new selforganized structures (Holling, 1986). Regime shifts may occur within one adaptive cycle or between adaptive cycles at different scales, and cause reorganization or even sometimes a complete ecosystem collapse (Allen et al., 2014). Such catastrophic regime changes, marked by species communi- 
ties loss and consequently, collapse of the ecosystem's functions have been recorded in many of the world's oldest lakes, like Baikal in Russia, Hövsgöl in Mongolia and Malawi in East Africa (Karabanov et al., 2004; Cohen et al., 2007; Burnet et al., 2011; Scholz et al., 2011). Based on the intensity of forcing, and their physical, chemical and biological properties these lakes had different capacities to adapt, restore and/or reorganize their panarchy. The adaptive capacity of an ecosystem is intrinsically related to its resilience (Allen et al., 2005; Allen and Holling, 2008), and therefore, research on sediment records from ancient lakes is important for understanding the past adaptive capacities, regime changes, and resilience of these unique ecosystems.

In Europe, such Quaternary archives are neighbouring lakes Ohrid and Prespa, located on the Balkan Peninsula. Since the Pliocene origin of their tectonic basins, more than $1 \mathrm{Ma}$ co-existence and co-evolution (Stanković, 1960) resulted in the oldest and most diverse permanent lake systems in Europe (Albrecht and Wilke, 2008; Levkov and Williams, 2012). Understanding the external and internal drivers for these basins is critical for determining the high level of biological endemism of especially Lake Ohrid. At present, the lake system has unique spatial interactions due to hydrological connectivity via a karstic system in Mt. Galičica (Anovski et al., 1997, 2001). About $20 \%$ of the Lake Ohrid water inflow originates from Lake Prespa, and, therefore, the much shallower and more nutrient rich Lake Prespa can potentially drive changes in Lake Ohrid (Matzinger et al., 2006). By applying a system analytical approach, Matzinger et al. (2006) assessed the anthropogenic influence on Lake Prespa, quantified the underground water and nutrient flow and developed a linear phosphorus (P) model. By using the 1960s' water-level high-stand of Lake Prespa $(\sim 855 \mathrm{~m}$ a.s.l.) as a baseline for the calculation, the model indicates that a $20 \mathrm{~m}$ water level decrease of Lake Prespa can cause a five-fold increase of its $\mathrm{P}$ concentration, which may lead to a $30 \%$ increase of the P load from Lake Prespa to Lake Ohrid (Matzinger et al., 2006). Such a scenario can potentially trigger a regime shift in the physico-chemical properties of Lake Ohrid and affect its fragile endemic community (Watzin et al., 2002; Matzinger et al., 2006, 2007). Therefore, parallel analysis of long-term temporal variations under changing climate boundary conditions from Quaternary sedimentary records of both lakes is important for identifying the potential influence of Lake Prespa on Lake Ohrid.

Between 2005 and 2012, multiple cores have been retrieved at different locations from lakes Ohrid and Prespa, the oldest dating to ca. 135.0 ka (Co1202, Ohrid; Vogel et al., 2010a) and 92.0 ka (Co1215, Prespa; Damaschke et al., 2013). While environmental variations in Lake Prespa were resolved at high resolution for the last ca. $92.0 \mathrm{ka}$ (Aufgebauer et al., 2012; Wagner et al., 2012; Panagiotopoulos et al., 2013, 2014; Cvetkoska et al., 2014a, 2015), the presence of hiatuses in cores retrieved from Lake Ohrid (Wagner et al., 2008; Vogel et al., 2010b; Lacey et al., 2014;
Zhang et al., 2016) hampered a detailed palaeoenvironmental comparison between the two lakes until today.

As part of the project Scientific Collaboration on Past Speciation Conditions in Lake Ohrid (SCOPSCO), a successful International Continental Scientific Drilling Program (ICDP) drilling campaign was carried out at Lake Ohrid in spring 2013. A sediment sequence spanning $>1.2 \mathrm{Ma}$ (Wagner et al., 2014a) was recovered at the "DEEP site" in the central part of the lake. Multi-proxy analyses of this sequence currently proceed towards understanding the influence of the past geological and environmental events on the biological evolution of the lake taxa, as one of the main project objectives.

Aiming to assess the potential interactions between the lakes, we compare Lake Prespa's dynamics, as already inferred from core Co1215 diatom, pollen, and geochemistry data with the diatom and selected bio(geochemical) data from the same age interval (ca. $92.0 \mathrm{ka}$ to present) of the DEEP site sediment sequence. Here, we apply the concept of panarchy and consider lakes Ohrid and Prespa as lower-scale entities of the higher hierarchical, landscape scale, as justified by their hydrological connection. Trends in the multiproxy data set are used to reconstruct and compare the adaptive cycles, regime shifts and assess the response mechanisms to external disturbances on ecosystem scale (e.g. lakes Ohrid and Prespa). At higher hierarchical level, we aim to assess the potential interconnectivity between the lakes in order to understand the cross-scale linkages and recognize the capacity of Lake Prespa as a driving force of regime shifts in Lake Ohrid.

\section{Environmental setting}

Harbouring more than 300 endemic species (Föller et al., 2015), Lake Ohrid, Macedonia/Albania $\left(41^{\circ} 01^{\prime} \mathrm{N}\right.$, $20^{\circ} 43^{\prime}$ E, $693 \mathrm{~m}$ a.s.l., Fig. 1) has the highest index of endemism of all ancient lakes, when its surface area of $358 \mathrm{~km}^{2}$ is taken into account (Albrecht and Wilke, 2008). With a mean and maximum water depth of 155 and $293 \mathrm{~m}$, respectively (Lindhorst et al., 2015), it is a deep, calciumbicarbonate $\mathrm{Ca}\left(\mathrm{HCO}_{3}\right)_{2}$ dominated, oligotrophic lake. The hydrological balance of the lake is regulated by $37.9 \mathrm{~m}^{3} \mathrm{~s}^{-1}$ inflow, of which $\sim 25 \%$ derives from direct precipitation, $\sim 25 \%$ from river input and $\sim 50 \%$ from the karst aquifers, and the outflow through the river Crni Drim, $(\sim 60 \%)$ and evaporation ( $\sim 40 \%$, Matzinger et al., 2006). The estimated water residence time is ca. 70 years. The average monthly air temperature of the surrounding area is $26^{\circ} \mathrm{C}$ during summer and $-1{ }^{\circ} \mathrm{C}$ in winter and the annual precipitation averages to 750 mm year $^{-1}$ (Wagner et al., 2009). Recent investigations revealed an increase in total $\mathrm{P}$ concentration from $\sim 1.3 \mathrm{mg} \mathrm{Pm}^{-3}$ in historic times (ca. 150 years ago) to $4.5 \mathrm{mg} \mathrm{P} \mathrm{m}^{-3}$ today (Matzinger et al., 2006, 2007). 


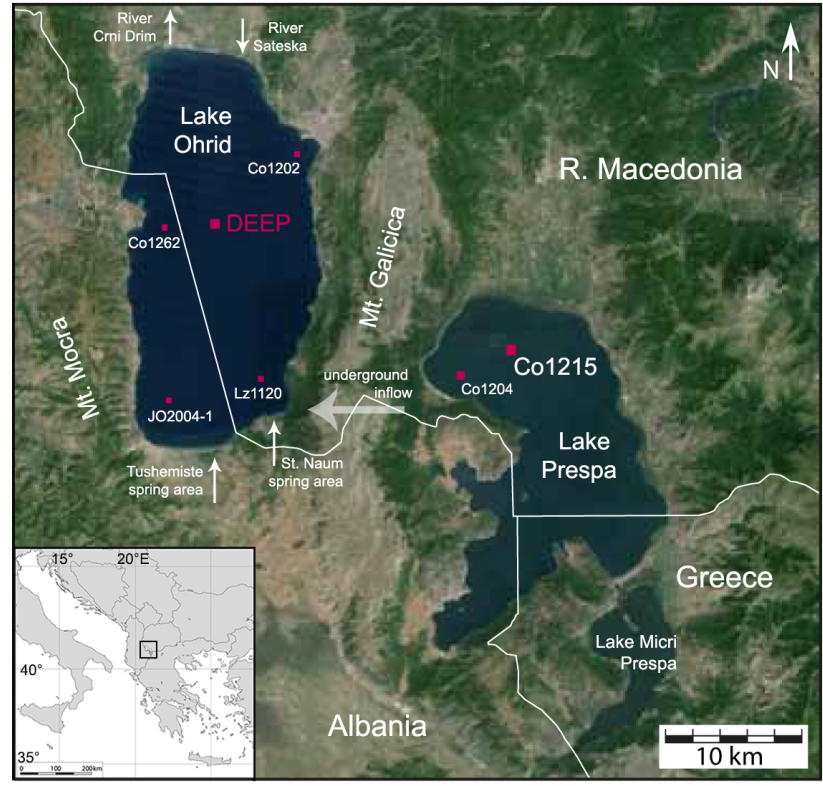

Figure 1. Map of the northern Mediterranean region showing the location of lakes Ohrid and Prespa. Marked in purple are the locations of the cores: JO2004 (Belmecheri et al., 2009), Lz 1120, Co1202, Co1262 and from field campaigns at Lake Ohrid between 2005 and 2012, cores Co1204 and Co1215 recovered from Lake Prespa during field campaigns in 2009 and 2011; (Wagner et al., 2009, 2010, 2012) and the DEEP site core 5045-1, retrieved during the SCOPSCO deep drilling campaign at Lake Ohrid in 2013 (Wagner et al., 2014a). Modified from Francke et al. (2016).

Lake Prespa, located at the border of Macedonia, Albania, and Greece $\left(40^{\circ} 46^{\prime}-41^{\circ} 00^{\prime} \mathrm{N}, 20^{\circ} 54^{\prime}-21^{\circ} 07^{\prime} \mathrm{E}\right.$, Fig. 1) is situated at $849 \mathrm{~m}$ a.s.l. It is a tectonic lake which belongs to a former lake complex, called Dessarets (Stanković, 1960), but its age is still uncertain. Although it hosts fewer endemic species, it has been suggested that the endemic faunal species might be older than those in Lake Ohrid (Karaman, 1971). In terms of its physical properties, Lake Prespa is a large, $254 \mathrm{~km}^{2}$, relatively shallow lake with $\sim 14 \mathrm{~m}$ mean and $\sim 48 \mathrm{~m}$ maximum water depth. At present, the estimated hydraulic residence time is ca. 11 years, but it varies highly with changing lake levels; and for example, at $\sim 19$ m mean water depth during the $1980 \mathrm{~s}$, this number was $\sim 17$ years (Matzinger et al., 2006). The water input, $16.92 \mathrm{~m}^{3} \mathrm{~s}^{-1}$, is via river inflow and catchment runoff $(56 \%)$, direct precipitation $(35 \%)$, inflow $(9 \%)$ from the nearby Lake Micri Prespa (Fig. 1), and groundwater input (no data available). The output is via evaporation $(52 \%)$, water abstraction for irrigation $(2 \%)$ and subsurface outflow through the karstic aquifers of Galičica Mountain (46\%, Matzinger et al., 2006). The average monthly temperature in the surrounding area is $21^{\circ} \mathrm{C}$ in summer and $1{ }^{\circ} \mathrm{C}$ in winter, and the annual precipitation varies between 720 in the lowlands and 1200 mm year $^{-1}$ on the mountains (Hollis and Stevenson, 1997). The lake is highly sensitive to external distur- bances (e.g. climate change) and water loss; major lake-level fluctuations including a lake-level decline of almost $10 \mathrm{~m}$ due to restricted precipitation and increased water abstraction for irrigation have been documented between 1950 and 2009 (Popovska and Bonacci, 2007). Recent monitoring programs of the lake revealed $\sim 31 \mathrm{mg} \mathrm{m}^{-3} \mathrm{TP}$ concentration (Matzinger et al., 2006), and $~ 162$ tyear $^{-1}$ TP input from the river tributaries (Krstić, 2012).

\section{Methodology}

\subsection{Core recovery and chronology}

Core "5045-1" was recovered at the DEEP site in the central part of Lake Ohrid within the scope of the SCOPSCO deep drilling campaign in 2013 (Fig. 1). Six parallel boreholes (AF) at $243 \mathrm{~m}$ water depth were drilled down to a maximum sediment depth of $569 \mathrm{~m}$ below the lake floor ( $\mathrm{m}$ blf) and a total $1526 \mathrm{~m}$ of sediment cores was recovered. Comprehensive details of the drilling procedure, sediment recovery and results from the preliminary analyses of core catcher samples are provided in Wagner et al. (2014a). The age model for the upper $247.8 \mathrm{~m}$ of the composite sequence of the DEEP site for the sediment core and downhole logging data is based on 11 tephrostratigraphic tie points (first order tie points), and on tuning (bio-)geochemical proxy data to orbital parameters (second order tie points) (Baumgarten et al., 2015; Francke et al., 2016). In order to compare the same age intervals in lakes Ohrid and Prespa, we analysed the uppermost $37.5 \mathrm{~m}$ of the DEEP site sequence, which represent the last ca. $92.0 \mathrm{ka}$ according to the age-depth model. This period is well-constrained by the occurrence of the Y5 tephra layer at ca. $39 \mathrm{ka}$, the Y3 tephra layer at ca. $29 \mathrm{ka}$, and the Mercato tephra layer at $8.5 \mathrm{ka}$ in the DEEP site sediment sequence (Leicher et al., 2016).

The age-depth model of the $17.7 \mathrm{~m}$ long core Co1215 from Lake Prespa is based on 11 tephrochronological tie points, radiocarbon ${ }^{14} \mathrm{C}$ dating, electron spin resonance (ESR) dating and comparison with the NGRIP ice core data. An age of ca. 92.0 cal ka BP was extrapolated for the base of the sequence; details are provided in Damaschke et al. (2013).

\subsection{Analytical work}

The analysis of the $37.5 \mathrm{~m}$ sequence from the DEEP site comprises non-destructive X-ray fluorescence scanning (ITRAX core scanner, Cox Analytical, Sweden) for potassium intensities (K), and measurements of total carbon (TC) and total inorganic carbon (TIC) by a DIMATOC 100 carbon analyzer (Dimatec Corp., Germany). The total organic carbon (TOC) content was calculated from the difference between TC and TIC. Total nitrogen (TN) was analysed using an elemental analyzer (vario MICRO cube, Elementar Corp.) after combustion at $1150{ }^{\circ} \mathrm{C}$ and used to calculate the ratio between TOC and TN (abbreviated as C / N). Bio- 
Table 1. Locations, sediment recovery and summary of methods used for the diatom analyses of cores 5045-1 from Lake Ohrid and Co1215 from Lake Prespa.

\begin{tabular}{|c|c|c|}
\hline & Lake Ohrid "5045-1" & Lake Prespa Co1215 \\
\hline Drill site location & $\begin{array}{l}\mathrm{N} 41^{\circ} 02^{\prime} 57^{\prime \prime}, \\
\mathrm{E} 020^{\circ} 42^{\prime} 54^{\prime \prime}\end{array}$ & $\begin{array}{l}\mathrm{N} 40^{\circ} 57^{\prime} 50^{\prime \prime}, \\
\mathrm{E} 20^{\circ} 58^{\prime} 41^{\prime \prime}\end{array}$ \\
\hline Water depth (m) & 243 & 14 \\
\hline Length of composite record (this study; m) & 37.5 & 17.7 \\
\hline Age (ka BP) & 92.0 & 92.0 \\
\hline Sample resolution for diatom analysis $(\mathrm{cm}, \mathrm{ka})$ & 16 , ca. $0.3-0.5$ & 8, ca. $0.1-0.4$ \\
\hline Total number of slides & 235 & 222 \\
\hline Stratigraphic plots of relative diatom abundances & \multicolumn{2}{|c|}{ Tilia/TGView v. 1.7.16. (Grimm, 1987) } \\
\hline Diatom assemblages zonation & \multicolumn{2}{|c|}{ CONISS (Grimm, 1987) } \\
\hline Multi-proxy stratigraphic diagram & \multicolumn{2}{|c|}{ C2 (Juggins, 1991-2007) } \\
\hline Ordination & $\begin{array}{l}\text { PCA }(\text { SD }=2.2) \\
\text { Canoco } 5 \\
\text { (ter Braak and Šmilauer, 2012) }\end{array}$ & $\begin{array}{l}\text { DCA }(\text { SD > 2.5), } \\
\text { R “stats" v. 0.8-2 } \\
\text { (R Core Team, 2012) }\end{array}$ \\
\hline
\end{tabular}

genic silica concentrations (BSi) were inferred by means of Fourier Transform Infrared Spectroscopy at the University of Bern, Switzerland following the method outlined in Vogel et al. (2008) and the calibration after Meyer-Jacob et al. (2014). All bio(geochemical) analyses are described in more detail in Francke et al. (2016).

Diatom analysis on the DEEP site core was performed on 235 samples in total (resolution $16 \mathrm{~cm}$, ca. $0.3-0.5 \mathrm{ka}$ ), prepared from freeze-dried sediment subsamples according to the method of Cvetkoska et al. (2012). Known aliquots of cleaned samples were used to estimate the absolute diatom concentrations, "DC" $\left([n]\right.$ valves $\times 10^{7} \mathrm{~g}^{-1}$ dry sediment), employing the sedimentation tray method of Battarbee (1986). Permanent diatom slides were prepared using Naphrax ${ }^{\circledR}$ as mounting medium. Around 350 diatom valves per slide were counted at $1500 \times$ magnification with an Olympus BX51 microscope. As an exception, at least 100 valves per sample were counted in diatom assemblages with low species diversity and/or concentration. Species identification followed Levkov et al. (2007), Levkov and Williams (2011, 2012), Cvetkoska et al. (2012, 2014b), Jovanovska et al. (2013), and Pavlov et al. (2013). Diatom accumulation rates, "DAR" $\left([n]\right.$ valves $\left.\times 10^{6} \mathrm{~cm}^{-2} \mathrm{ka}^{-1}\right)$ were calculated by multiplying the dry sediment accumulation rates, "SAR" $\left(\mathrm{g} \mathrm{cm}^{-2} \mathrm{ka}^{-1}\right)$ and the DC, Anderson (1989). To assess the preservation quality in the sequence, the $F$ index of Ryves et al. (2001) was calculated for Cyclotella fottii Hustedt as a proportion of the number of pristine valves and the total number of classifiable valves of the species. Values of $F=0$ indicate partial dissolution of all valves and $F=1$ means ideal preservation. The variation in the di- atom data was explored by detrended correspondence analysis, "DCA", and with a gradient length of 2.2 , principle component analysis, "PCA" was appropriate (Jongman et al., 1995). To maximize the apparent variance, PCA was run on species morphotypes at a sub-species level. The Spearman's rho rank-correlation test ("stats" version 0.8-2; R Core Team, 2012) was used to analyse the correlation between the dominant diatom species abundance, the DAR, DC and the (bio)geochemistry data (Table 3). At both sites, the constrained stratigraphic diatom zones were defined by the incremental sum of squares distance metric of the CONISS program (Grimm, 1987).

The analytical approaches of the geochemistry, isotope, lithology, pollen, and diatom analyses of Lake Prespa core Co1215 have been extensively described in Aufgebauer et al. (2012), Wagner et al. (2012), Damaschke et al. (2013), Leng et al. (2013), Cvetkoska et al. (2014a, 2015), and Panagiotopoulos et al. (2014). Diatom analysis on core Co1215 was carried out on 222 samples in total (resolution $8 \mathrm{~cm}$, ca. $0.1-0.4 \mathrm{ka}$ ) and the variation in the diatom data was analysed with DCA based on the $>2.5$ gradient length (Cvetkoska et al., 2015). Comparative details of the diatom analytical methods applied to both site cores, DEEP and Co1215, are presented in Table 1.

\section{Principal diatom results and environmental controls}

In total, 141 diatom species were identified for the last ca. $92.0 \mathrm{ka}$ of the DEEP site core. The diatom diagram (Fig. 2) displays 31 species and morphotypes, present at $>2 \%$ in the assemblages. The diatom assemblages are dominated by 


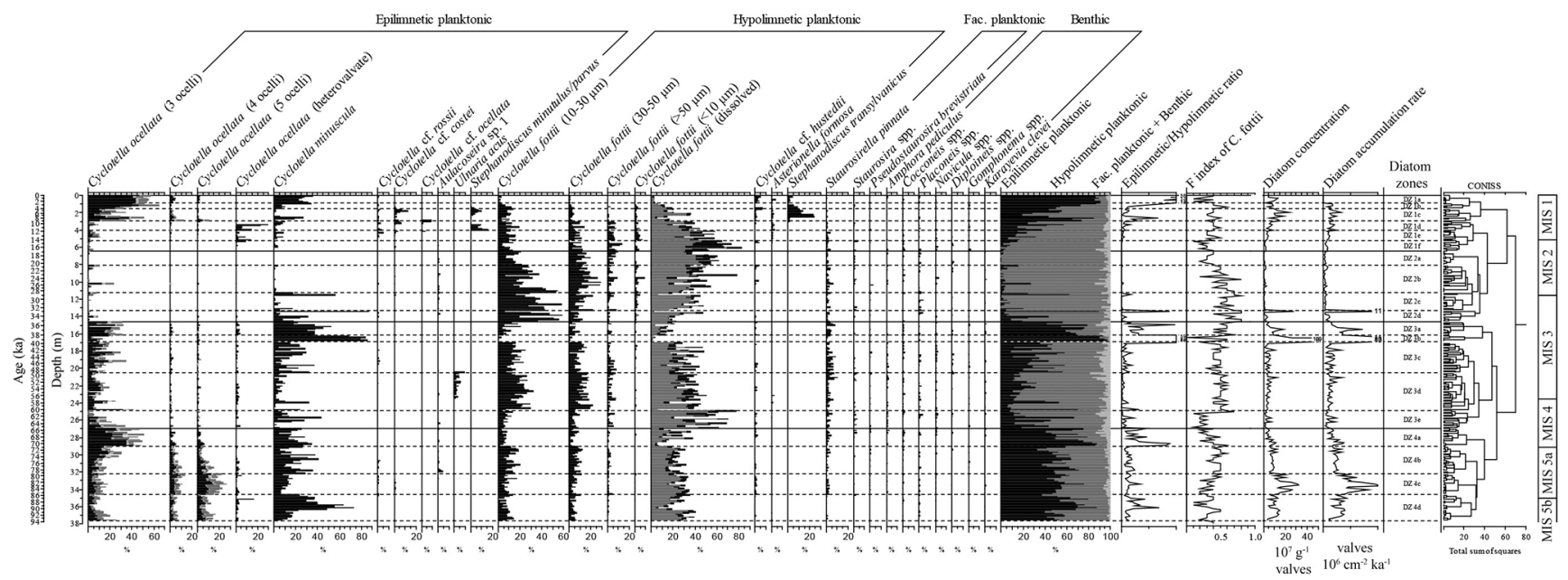

Figure 2. Stratigraphic diatom diagram showing species with $>2 \%$ abundance in Lake Ohrid DEEP site core 5045-1, $F$ index of $C y c l o t e l l a$ fottii, diatom concentrations $\left([n]\right.$ valves $\times 10^{7} \mathrm{~g}^{-1}$ dry sediment) and diatom accumulation rates $\left([n]\right.$ valves $\left.\times 10^{6} \mathrm{~cm}^{-2} \mathrm{ka}^{-1}\right)$. Diatom zone boundaries are defined by CONISS, Marine Isotope Stages (MIS) boundaries after Lisiecki and Raymo (2005).

planktonic taxa, mainly from the genus Cyclotella (Kützing) Brébisson. The facultative planktonic "FP" and benthic life habitat groups are represented with higher species numbers, but low overall relative proportions due to the large depth of the coring location, which is beyond the optimal depth for their distribution in the lake. The most abundant FP and benthic genera are Amphora Kützing, Cocconeis Ehrenberg, Gomphonema Ehrenberg, Diploneis Ehrenberg ex Cleve, Navicula Bory, Staurosira Ehrenberg and Staurosirella D. M. Williams et F. E. Round. Following previous studies of Reed et al. (2010), Cvetkoska et al. (2012), and Wagner et al. (2014a), the dominant planktonic taxa were split in morphotypes, useful to test the link between the longterm ecosystem dynamics and species evolution in the DEEP site record. Cyclotella fottii was initially split in four morphotypes, based on valve size, and size and shape of the central area, while the $C$. ocellata Pantocsek complex was split in eight morphotypes based on valve size and number of ocelli in the central area.

Based on previous studies (Stanković, 1960; Allen and Ocevski, 1976), the vertical distribution of the phytoplankton in Lake Ohrid is primarily driven by temperature, in combination with light, nutrient availability, and water mixing. The last $92.0 \mathrm{ka}$ of the DEEP site diatom record are generally dominated by three planktonic species with different autecology, C. fottii, C. ocellata and C. minuscula (Jurilj) Cvetkoska. Cyclotella fottii is an oligotrophic, stenothermic species, adapted to low temperatures; viable populations of the species have been found at more than $100 \mathrm{~m}$ water depth, where the light availability is far below the optimal intensity for photosynthesis and temperature is permanently reduced (Stanković, 1960). This indicates that low light availability is not limiting $C$. fottii, while temperature is likely more important factor for its vertical distribution and abundance in the phytoplankton. Cyclotella ocellata is an ecologically successful species of wide distribution, though, in Lake Ohrid, it dominates in the epilimnion during the spring and summer season (Stanković, 1960; Zhang et al., 2016). This is the zone of warmer temperatures, higher light availability, but lower nutrients than the hypolimnion. However, in Lake Ohrid C. ocellata has been interpreted as mesotrophic and an indicator of increased productivity in comparison to C. fottii (Wagner et al., 2009; Lorenschat et al., 2014; Zhang et al., 2016). As a result of the lack of autecological data for C. minuscula we relied on a previous study by Cvetkoska et al. (2014a), the findings of Winder et al. (2009), and the comparison with the geochemical proxies. At the DEEP site, maxima in the relative abundance of $C$. minuscula correspond to the Y5, Y3, and the Mercato tephra layers and peaks in $\mathrm{K}$ intensities. This is also shown by the high-resolution study of the diatom response to the Y5 tephra impact on lakes Ohrid and Prespa by Jovanovska et al. (2016). The tephra influx/deposition increases the silica availability, which is enhancing the diatom productivity, consequently leading to strong competition for nutrients and light resources.

At present, most of the FP and benthic species in Lake Ohrid are found between the shallow littoral zone and $\sim 50 \mathrm{~m}$ water depth (Levkov et al., 2007). The overall low relative abundances, 5-15\%, of these species in the DEEP site record result from the coring location, and thus add little supporting evidence to the interpretation. However, the periods of their slightly increased abundances during the last ca. $92.0 \mathrm{ka}$ can be interpreted as an indication for intensified transport from the shallower parts of the lake due to wind-induced wave activity and lake-internal currents (Vogel et al., 2010c).

The PCA (Fig. 3, Table 2) displays C. fottii, C. ocellata (3 ocelli) and C. minuscula aligned along the low-high values range of PCA Axis 1, reflecting the overall trend of 
Table 2. Summary results of the unconstrained PCA ordination of 235 diatom samples from Lake Ohrid DEEP core and the DCA ordination of the 222 samples from Lake Prespa core Co1215 (modified from Cvetkoska et al., 2015). SD (PCA) $=2.2$, SD $($ DCA) $>2.5$.

\begin{tabular}{|c|c|c|c|c|}
\hline & Axis 1 & Axis 2 & Axis 3 & Axis 4 \\
\hline \multicolumn{5}{|c|}{ Lake Ohrid, PCA Axes } \\
\hline Eigenvalues & 0.44 & 0.13 & 0.09 & 0.06 \\
\hline Explained variation (cumulative) & 44.46 & 57.08 & 66.30 & 72.24 \\
\hline \multicolumn{5}{|c|}{ Lake Prespa, DCA Axes } \\
\hline Eigenvalues & 0.47 & 0.23 & 0.17 & 0.14 \\
\hline Decorana values & 0.50 & 0.32 & 0.12 & 0.08 \\
\hline
\end{tabular}

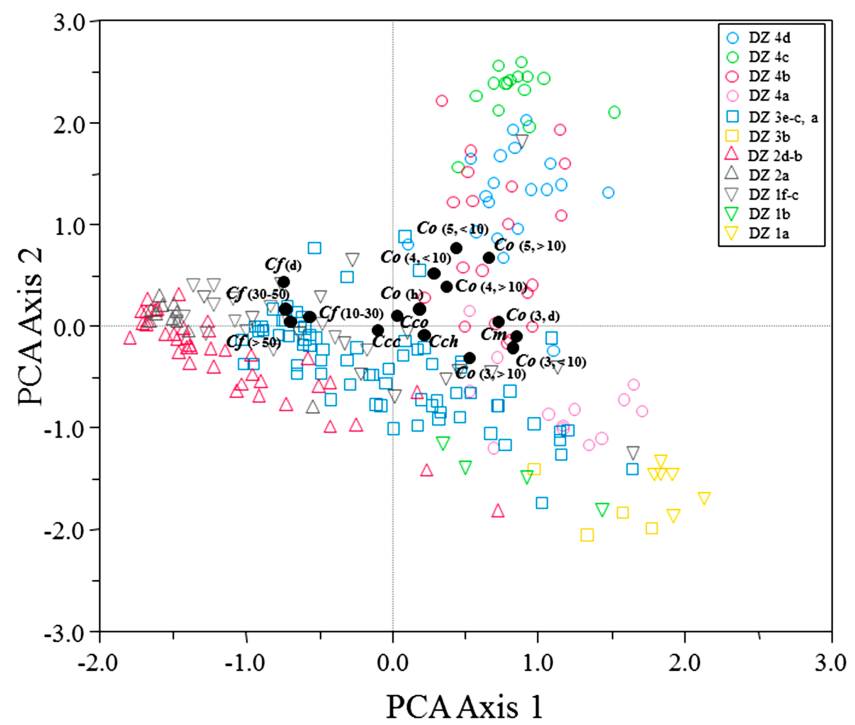

Figure 3. Biplot of PCA Axis 1 vs. PCA Axis 2 sample and species scores from Lake Ohrid DEEP site core (5045-1). Symbol keys for diatom zones and sub-zones in top right corner. Selected diatom taxa and morphological splits of Cyclotella fottii ( $C f$, size in $\mu \mathrm{m})$ and Cyclotella ocellata (Co) are plotted, where numbers in brackets refer to size splits $(\mu \mathrm{m})$ and ocelli number in $C$. ocellata. Explanation: $\mathrm{Cm}=$ Cyclotella minuscula,$C c h=C y c l o t e l l a$ cf. hustedtii, Ccc = Cyclotella $\mathrm{cf}$. costei, Cco =Cyclotella cf. ocellata,$(\mathrm{d})=$ dissolved.

temperature-driven diatom response, due to over-dominance of $C$. fottii. PCA Axis 2 displays clustering of the $C$. ocellata morphotypes with 4 and 5 ocelli along the positive values, reflecting their dominance during the last interglacial. For both axes, the Holocene signal appears muted between ca. 7.0-2.0 ka due to presence of taxa, like Stephanodiscus transylvanicus Pantocsek and S. minutulus (Kützing) Cleve et Möller, indicative of nutrient change per se (Kilham et al., 1986; Wagner et al., 2009; Cvetkoska et al., 2012; Zhang et al., 2016).

The DC and DAR (Figs. 2, 4) show high positive correlation values with the other (bio)geochemistry proxies $(\mathrm{BSi}$, TOC, TIC, C / N, see Table 3). In Lake Ohrid sediments, BSi and TOC are of mainly authigenic origin, indicating the primary productivity in the lake (Wagner at al., 2009; Vogel et al., 2010b; Francke et al., 2016). In addition, by adjusting the DC to the sedimentation rates, DAR can be used to qualitatively assess the overall, glacial-interglacial scale trends of diatom productivity in the record.

Regarding the interpretation of the $\mathrm{C} / \mathrm{N}$ ratios, as an indication for the source of organic matter "OM", we point to the study of Lacey et al. (2014) on the Lini sequence where it was demonstrated by means of Rock Eval pyrolysis that in Lake Ohrid, the "OM" is predominantly of pure algal source. The contribution of vascular vegetation to the $\mathrm{OM}$ at the DEEP site is also highly unlikely due to the coring location. Nonetheless, low $\mathrm{C} / \mathrm{N}$ ratios $(\sim 4)$ during the glacials can also result from enhanced supply of clay-bound ammonium following mineral soil erosion rather than algal OM, along with ongoing organic carbon degradation (Holtvoeth et al., 2016).

In nature, the biotic response to multiple environmental factors depends on the response to the single dominant (limiting) driver, and the chance of a driver of large effect being present increases with the number of drivers (Brennan and Collins, 2015). On a glacial-interglacial scale, multiple environmental drivers change synchronously with rising and/or declining temperatures, like the light and nutrient availability. In case of Lake Ohrid, the autecology of the species (e.g. alternations between $C$. fottii and $C$. ocellata dominance) and the significant correlation of their relative abundances with the other productivity related proxies (TOC, BSi, DC, DAR) allow us to infer the orbital timescale trends in the diatom data as primarily driven by the large-scale temperature changes. Consistent with the interpretation of the diatom response at the Lini site (core Co1262; Zhang et al., 2016), we do not exclude the influence of other drivers, like nutrients, wind-induced water mixing, thermal stratification, light etc., but consider these factors as drivers that may play a more important role during millennial timescale events. 


\section{Ecosystems dynamics}

In the DEEP site sequence, four major hierarchical diatom zones (DZ 1-4, Fig. 2), each divided into 4-6 subzones, were identified during the last ca. $92.0 \mathrm{ka}$. The diatoms are compared to selected geochemistry data, i.e. the biogenic silica content $(\mathrm{BSi})$ and potassium $(\mathrm{K})$ intensities inferred from XRF core scanning in the record (Fig. 4). Diatom zones are discussed according to the Marine Isotope Stages (MIS) (Lisiecki and Raymo, 2005). For a detailed overview of the diatom data and palaeoenvironmental interpretation of Lake Prespa core Co1215, the reader is referred to Cvetkoska et al. (2014a, 2015).

The biological, chemical and physical components of the ecosystems constantly fluctuate, although sometimes at slow rates (Scheffer and Carpenter, 2003). Therefore, we apply the term regime, referring to the periods of diatom and bio(geochemistry) inferred ecosystems dynamics in terms of trophic state and/or lake level. Changes in the diatom communities' structure related to changes in the inferred lake's dynamics are considered as regime shifts. In case of Lake Prespa, multiple shifts between planktonic and benthic species-dominated assemblages mark the stratigraphic diatom data. The dominance of benthic diatom assemblages reflects the lower lake-level regimes, and the related physical changes in habitat distribution, but does not indicate higher lake productivity. Indeed, shifts in Lake Prespa trophic regimes are marked by changes within the planktonic diatom assemblages, (e.g. from Cyclotella to Aulacoseira dominated assemblages).

Regarding the comparison between both sediment sequences, the age models of Ohrid DEEP site core and Prespa core, Co1215 are independent and only few direct correlation points via the occurrences of well-known tephra layers exist (e.g., the Y5 and Mercato tephra). The dating errors of Ohrid DEEP site core are on the $2 \sigma$ confidence level for the tephra layers, while each cross-correlation point to orbital parameters include an error of \pm 2000 years (Francke et al., 2016; Leicher et al., 2016). The dating errors of Lake Prespa core, Co1215 can be estimated to be $<1000$ years for the last $40 \mathrm{ka}$, but increase significantly to several thousands of years in the lower part, where ESR dating, poorly known tephrostratigraphy, and tuning of organic matter content to marine and ice core records provide less well constrained chronological tie points (Damaschke et al., 2013). Therefore, the comparisons of the diatom data (and inferred temperature/trophic changes) need to be done carefully. This is especially the case of the single spikes, which may easily have an offset of several centuries to millennia.

\subsection{The last interglacial, MIS $5(92.0-71.0 \mathrm{ka}$; DZ 4d-b)}

\subsubsection{MIS 5b (92.0-85.0 ka; DZ 4d)}

The MIS 5b period in Lake Prespa diatom record was interpreted as an unstable, transitional phase of moderate, but variable moisture availability and temperatures. Lowlake-level phases characterized by oligo-mesotrophic conditions in Lake Prespa occurred at 90.0, 88.4, and 85.6 ka (Cvetkoska et al., 2015).

The basal diatom zone, (DZ 4d) in Lake Ohrid DEEP site core is marked by dominance of the $C$. ocellata complex until $88.7 \mathrm{ka}$, when $C$. minuscula peaks with ca. $65 \%$ relative abundance, taking over a major part of the epilimnetic diatom productivity to the end of MIS 5b (Figs. 2, 4). The autecology of $C$. minuscula indicates that its dominance was favoured by the increased clastic input in this part of the record, rather than warmer temperatures, as it is also reflected by the corresponding increase of K intensities and SAR (Fig. 4) (Francke et al., 2016). The low DAR match well with low BSi, TOC and $\mathrm{C} / \mathrm{N}$ ratio, suggesting less productivity and/or preservation of the organic matter (Francke et al., 2016). The overall comparison between both records indicates that both lakes responded to the similar, transitional phase of moderate temperatures, but lake-level fluctuations in Lake Prespa do not find an equivalent in Lake Ohrid DEEP site.

\subsubsection{MIS 5a (85.0-71.0; DZ 4c, b)}

In Lake Prespa, a climatic drought between 85.0 and $83.0 \mathrm{ka}$ causing a lake-level decline and a shift to a regime of highest productivity in the record was interpreted from the diatom and pollen data (Panagiotopoulos et al., 2014; Cvetkoska et al., 2015). A second lake-level low-stand at Lake Prespa between 77.6 and $76.6 \mathrm{ka}$, related to decreased effective precipitation, occurred before the end of the last interglacial, which is marked at $70.2 \mathrm{ka}$ in the diatom record (Cvetkoska et al., 2015). Sedimentological, hydroacoustic data and bivalves indicate another lake-level low-stand around $74.0 \mathrm{ka}$ (Wagner et al., 2014b), but this is not reflected in the Co1215 diatom data.

In Lake Ohrid DEEP site diatom record, the period between ca. 85.0 and $78.0 \mathrm{ka}$ is characterized by the dominance of $C$. ocellata morphotypes with 4 and 5 ocelli (Fig. 2) and high overall DC and DAR (Figs. 2, 4). Similar diversification and presence of different $C$. ocellata morphotypes during MIS 5, MIS 3 and the Holocene was observed by Reed et al. (2010) and Cvetkoska et al. (2012). To this point, the hypothesis of climatically triggered species evolution seems quite plausible, even though revealing the nature of this diversification requires more data from the earlier Quaternary. The higher productivity inferred from the diatom data in this part of the record is also seen in the increased BSi content, high TOC values and $\mathrm{C} / \mathrm{N}$ ratio (Fig. 4). In a phase of constant SAR and catchment vegetation dominated by 


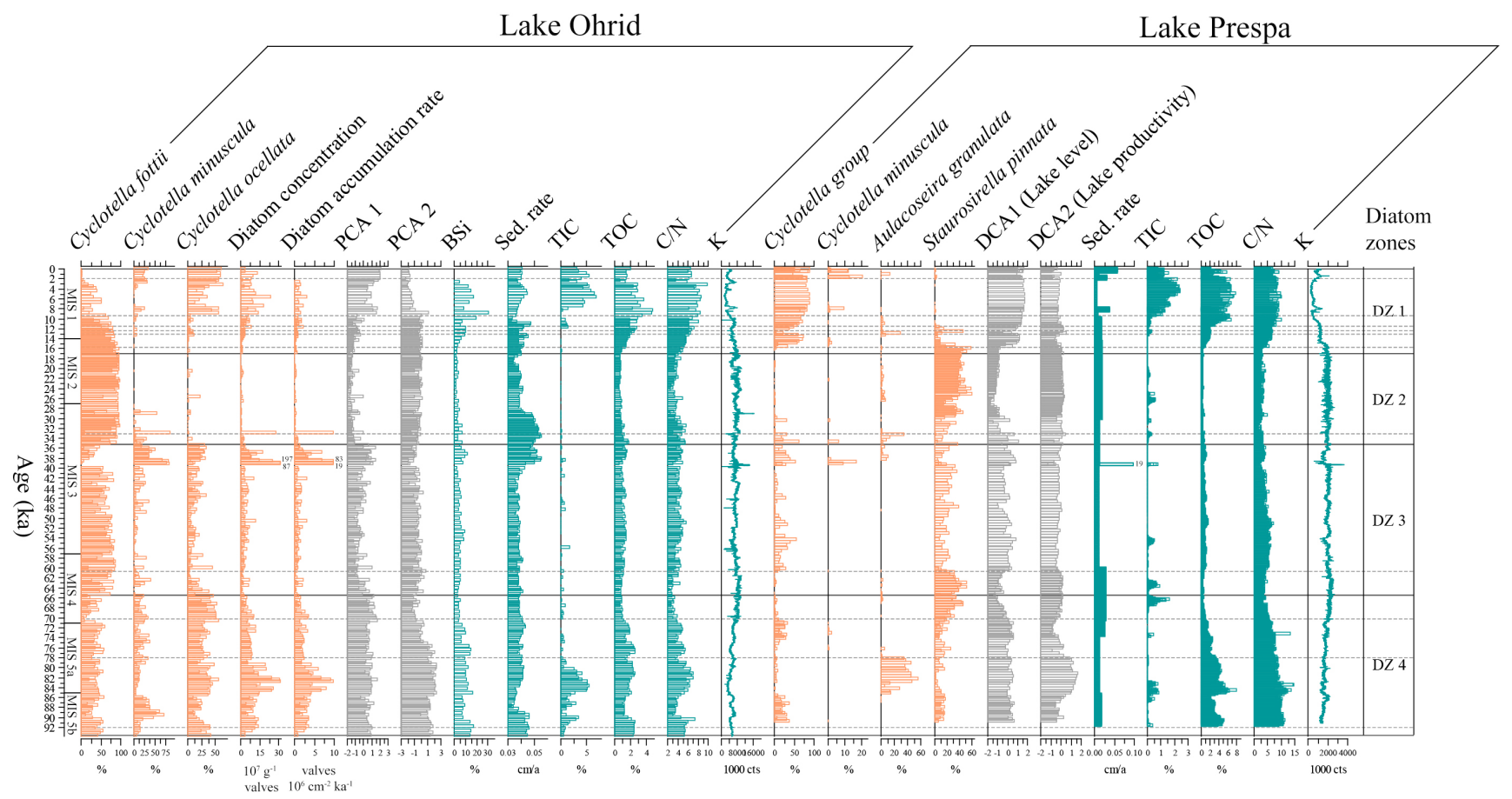

Figure 4. Comparison diagram between Lake Ohrid core 5045-1 and Lake Prespa core Co1215 showing the relative abundance data of selected diatom species, the PCA 1 and 2 sample scores; DC and DAR, the sediment accumulation rates (SAR) and the biogenic silica content (BSi, \% weight) of Lake Ohrid core DEEP. Prespa DCA 1 and 2 sample scores represent lake level and productivity. Displayed are the diatom zones (DZ 1-4) of Lake Ohrid core DEEP; the dotted lines mark the six major diatom zones of Lake Prespa core Co1215 (Cvetkoska et al., 2015). Selected geochemical proxies from Lake Ohrid core DEEP: total organic carbon (TOC), total inorganic carbon (TIC), C / N ratio and potassium (K); data from Francke et al. (2016); Lake Prespa core Co1215: TOC, TIC, C / N ratio, K; data from Wagner et al. (2012) and S. pinnata (\%), data from Cvetkoska et al. (2015). The MIS boundaries are from Lisiecki and Raymo (2005).

Table 3. Spearman's rho $(q)$ coefficient values for the correlations between selected diatom data, and geochemical proxies from Lake Ohrid DEEP site core.

\begin{tabular}{lrccrr}
\hline \multirow{2}{*}{ Spearman's correlation } & \multicolumn{3}{c}{ Cyclotella } & \multirow{2}{*}{ DC } & \multirow{2}{*}{ DAR } \\
\cline { 2 - 4 } & fottii & ocellata & minuscula & & \\
\hline TIC (\%) & -0.48 & 0.47 & 0.32 & 0.45 & 0.35 \\
TOC $(\%)$ & -0.36 & 0.50 & $/$ & 0.64 & 0.50 \\
BSi & -0.45 & 0.53 & 0.30 & 0.75 & 0.7 \\
C / N & -0.40 & 0.53 & $/$ & 0.63 & 0.47 \\
K & 0.38 & -0.41 & $/$ & -0.60 & -0.43 \\
\hline
\end{tabular}

All presented values are significant at $p<0.05$. " /" low values and/or no significant correlation.

mesophilous/montane trees (Sadori et al., 2016), this implies a temperature-related increase in the diatom productivity. The diatom signal of warmer climate is also supported by the high TIC content, indicative of increased endogenic calcite precipitation and/or preservation. A small increase in the abundance of $C$. fottii at ca. $76.5 \mathrm{ka}$, correlates with a return to dominance of the typical $C$. ocellata morphotypes.

The diatom and geochemistry data show that the overall dynamics of the Lake Ohrid DEEP site during MIS 5 are primarily related to the regional trends in climate change, from cold/dry (MIS 5b) to warmer/wetter conditions during MIS 5a (Bar-Matthews et al., 2003; Martrat et al., 2004). The absence of similar abrupt peaks in both records, DEEP and Co1215, and the lack of mesotrophic species and bio(geochemical) evidence for a lake-level decline in Lake Ohrid support the notion that the periods of low lake levels and highest productivity in Prespa between 85.0 and $71.0 \mathrm{ka}$ did not affect Lake Ohrid, at least in its deepest and central parts. 


\subsection{The last glacial, MIS 4-2 (71.0-14.0 ka; DZ 4-1f)}

\subsubsection{MIS 4 (71.0-57.0; DZ 4a, 3e, part of DZ 3d)}

In Lake Prespa, the glacial conditions during MIS 4 triggered a progressive opening of the landscape (Panagiotopoulos et al., 2014) and a regime shift to low lake level, evident by low plankton abundances and diatom growth restricted to the shallow littoral habitats in a low productive lake (Cvetkoska et al., 2015).

Contrary, the glacial climate signal in Lake Ohrid DEEP site diatom record appears muted between 70.5 and $65.3 \mathrm{ka}$ due to the high relative proportions, 30-50\%, of the epilimnetic, thermophilous, spring/summer species $C$. ocellata (Fig. 2, DZ 4a). At the same time, the low DAR, BSi and TOC point to low diatom productivity and/or enhanced OM decomposition. High $C$. minuscula abundance and $\mathrm{K}$ intensities in this period (Fig. 4), indicative of enhanced clastic supply due to catchment erosion, are consistent with climate cooling. Nonetheless, the high relative abundances of C. ocellata between ca. 70.5 and $65.3 \mathrm{ka}$ indicate that probably the spring/summer temperatures of the epilimnetic zone were still favourable for its growth. This implies a gradual transition of Lake Ohrid from interglacial to glacial conditions, unlike Lake Prespa, where the MIS 5/4 transition is marked with a sharp boundary at ca. $70.2 \mathrm{ka}$.

The low proportions of epilimnetic taxa and dominance of C. fottii between 65.3 and $60.0 \mathrm{ka}$ (Fig. 2) in a zone of low preservation quality is indicative of low water temperatures and weak thermal stratification of the lake. In addition, the high proportions and/or dominance of $C$. fottii morphotypes $>30 \mu \mathrm{m}$ can be related to ultra(-oligotrophic) conditions, and consequently low competition and decreased grazing pressure, reflecting the cold glacial climate conditions. Similarly, large-celled diatom populations have been noted in other ancient lakes (e.g. Baikal, Hövsgöl) and it is supposed that they reflect oligotrophy, in contrast to smaller-celled diatoms which are more competitive in conditions of limiting nutrients and light (Stoermer et al., 1989; Edlund et al., 2003).

\subsubsection{The interstadial, MIS 3 (57.0-29.0 ka; part of DZ 3d, DZ 3c-a, DZ 2d, c)}

In Lake Prespa, the increased moisture availability at the interstadial onset prompted an increasing lake level, but the productivity remained low until $38.2 \mathrm{ka}$. Aridification and/or cooling were inferred from the diatom and pollen data at ca. 29.0 ka (Panagiotopoulos et al., 2014; Cvetkoska et al., 2015).

The start of the interstadial warming in the DEEP site diatom record is documented between ca. 57.5 and $52.0 \mathrm{ka}$ by a successive increase in the relative proportions of $C$. ocellata (25-35\%, Fig. 2) and BSi concentrations (Fig. 4), as well as decreasing $\mathrm{K}$ intensities. However, low BSi, TOC, DAR and DC in assemblages dominated by $C$. fottii and $C$. minuscula between 57.5 and 35.0 ka suggest low productivity and/or enhanced decomposition, and similarly, as in Prespa indicate that the interstadial warming was insufficient to enhance the dominance of the epilimnetic, thermophilous species. The decline of C. ocellata to $<5 \%$ and increased abundances of C. fottii (Fig. 2) indicate the return to colder conditions after ca. $33.0 \mathrm{ka}$, culminating in the return to glacial climatic conditions in Lake Ohrid at ca. $28.3 \mathrm{ka}$.

During MIS 3, a change in the structure and productivity of the diatom assemblages in Lake Prespa core Co1215 was related to the joined effect of the CI/Y5 tephra and the inferred climate aridity/cooling at ca. $39.3 \mathrm{ka}$ (Wagner et al., 2012; Leng et al., 2013; Panagiotopoulos et al., 2014; Cvetkoska et al., 2015).

Similarly, the most notable features of MIS 3 in Lake Ohrid are two maxima in DAR and DC between 39.2 and $38.8 \mathrm{ka}$ and at ca. $29.0 \mathrm{ka}$, prompted by ca. 85 and ca. $55 \%$ relative abundance of $C$. minuscula, respectively (Fig. 2). Both events coincide with high $\mathrm{K}$ intensities (Fig. 4), and correspond to the Y5 and Y3 tephra layers in the DEEP site sequence (Leicher et al., 2016). The diatoms indicate that the Y5 and Y3 tephra deposition disturbed the diatom communities by creating conditions of low transparency and high silica availability that enhanced the dominance of small celled Cyclotella species, due to the strong competition for nutrients and light resources. In a case study with leaching experiments on fresh ash samples from Etna eruptions, D' Addabbo et al. (2015) showed that there is only a small impact of tephra on Lake Ohrid water, except for $\mathrm{Si}$ and $\mathrm{F}$ saturation. Here, for example, the over-dominance of $C$. minuscula after the Y5 tephra impact in both lakes (this study, Cvetkoska et al., 2015; Jovanovska et al., 2016), is compensated by its small valve size $(3-7 \mu \mathrm{m})$ as superior adaptation enhancing its competitive strength during such conditions.

\subsubsection{The last glacial maximum, MIS $2(29.0-14.0 \mathrm{ka}$; DZ 2b, a, 1f)}

During the LGM, Lake Prespa experienced low productivity and low lake levels until $15.7 \mathrm{ka}$, and the diatom communities were dominated by facultative planktonic and benthic species (Cvetkoska et al., 2014a, 2015).

In Lake Ohrid, minima in DAR, DC, and low BSi content between ca. 29.0 and $13.6 \mathrm{ka}$ (Fig. 2) indicate low productivity and low temperatures. The low TOC and TIC (Fig. 4) support this interpretation and suggest enhanced decomposition of the organic matter due to cold/dry glacial regime (Wagner et al., 2009; Vogel et al., 2010b; Francke et al., 2016). Similar conditions with winter-ice cover at least in the littoral zone, frequent complete overturn of the lake, substantial opening of the landscape and reduction of vegetation belts were interpreted from multi-proxy analyses of other Lake Ohrid cores Lz1120 and Co1202 (Wagner et al., 2009; Vogel et al., 2010b), and from the DEEP site pollen record as well (Sadori et al., 2016). 
In terms of diatom response, the similar pattern of glacial assemblages dominated by large, robust valves of $C$. fottii, was also observed in the previous diatom records from Lake Ohrid (Wagner et al., 2009; Reed et al., 2010; Cvetkoska et al., 2012). Such similarity indicates that this is a "glacialclimate" driven regime of low productivity and diversity, and not just an artifact of taphonomic bias due to weak preservation. In general, both lakes seem to have buffered climate change during the LGM, since no major changes of the diatom communities, and/or species extinctions have been observed in the diatom records.

\subsection{Termination I and the Holocene, MIS 1 (14.0 ka to present; DZ 1e-a)}

Unlike the strong response of Lake Prespa to the wetdry-wet phases between 15.7 and $12.3 \mathrm{ka}$ due to the Bølling/Allerød (B/A) and Younger Dryas (YD) (Panagiotopoulos et al., 2013; Cvetkoska et al., 2014a), a first signal of climate warming subsequent to the LGM in Lake Ohrid derives from an unusual $15 \%$ abundance of "Janus", e.g., heterovalvate cells of C. ocellata at ca. $14.0 \mathrm{ka}$ (Fig. 2), The formation of heterovalvate cells is a phenomenon observed in many diatoms and often related to variation in nutrients, $\mathrm{pH}$ or temperatures (McBride and Edgar, 1998; Stoermer, 1967; Teubner, 1995). Their increased abundances at Lake Ohrid DEEP site core can be tentatively related to improved temperature and light conditions at the end of the LGM, as supported by somewhat higher DAR, DC, TOC and BSi between 13.6 and $11.2 \mathrm{ka}$ (Figs. 2, 4). At the same time, low TIC implies frequent mixing of the water column and dissolution of calcite during cold/dry winters (Vogel et al., 2010b; Francke et al., 2016).

Indeed, Lacey et al. (2014) and Zhang et al. (2016) interpreted the changes between 12.3 and $11.8 \mathrm{ka}$ in the bio(geochemical) and diatom data set of the "Lini" core Co1262 as reflection of the YD climate reversal. However, this record dates back to $12.4 \mathrm{ka}$ only and does not provide complete insights into the MIS 2/1 transition. Due to the sampling resolution and presence of hiatuses, cores Lz1120 and Co1202 from Lake Ohrid (Fig. 1) only provided incomplete or inconclusive results for this period (Wagner et al., 2009, 2012; Reed et al., 2010; Vogel et al., 2010a; Cvetkoska et al., 2012). We thus tentatively relate the weakness of response observed at the DEEP site to a combination of the depth at the coring location, low temperatures, and low nutrient availability prior to $11.2 \mathrm{ka}$.

While a rapid water-level increase in Lake Prespa was inferred between 10.0 and $8.0 \mathrm{ka}$ (Panagiotopoulos et al., 2013; Cvetkoska et al., 2014a), in Lake Ohrid DEEP site record, the presence of Stephanodiscus species, indicative of increased nutrient availability, and slightly increased DC and DAR during low SAR imply enhanced productivity between 11.2 and $9.0 \mathrm{ka}$. A comparable trend of increased productivity was observed at the Lini site (Lacey et al., 2014), while Zhang et al. (2016) found similar trends of water temperatureinduced lake productivity with an interruption between 10.2 and $9.5 \mathrm{ka}$.

Based on core Co1215 diatom data, sustained moisture availability, high lake levels, and oligo-mesotrophic regime prevailed in Lake Prespa between 7.9 and $1.9 \mathrm{ka}$ (Cvetkoska et al., 2014a, 2015). At Lake Ohrid DEEP site, maximum BSi content, high TIC and TOC concentrations, and diatom assemblages co-dominated by $C$. ocellata and $S$. transylvanicus between ca. 8.9 and $4.8 \mathrm{ka}$ (Figs. 2, 4) indicate high lake productivity. These conditions are rather indicative of warm mid-Holocene climate than high nutrient supply from Lake Prespa. Rising water-levels at Prespa could have led to higher water supply to Lake Ohrid, but rising lake level would have also led to a decrease in the nutrient concentrations in the water (Matzinger et al., 2006).

The mid-Holocene at Lake Ohrid is punctuated by two synchronous peaks of $C$. ocellata (ca. 5-7 $\mu \mathrm{m}$ ) and $C$. minuscula, with sum abundances of ca. 50 and $75 \%$ at ca. 8.5 and $7.9 \mathrm{ka}$, respectively, co-occurring with peaks in K (Figs. 2, 4). These pronounced signals are likely related to the Mercato tephra layer in the DEEP site sequence (Leicher et al., 2016; Francke et al., 2016) and the " $8.2 \mathrm{ka"} \mathrm{cold} \mathrm{event.} \mathrm{But,} \mathrm{delin-}$ eating the exact reasons for the delay of the peaks in diatoms by ca. 300 or 400 years requires a high-resolution study.

Around $1.0 \mathrm{ka}$, the combination of human impact, climate aridification and decreased summer precipitation during the "Medieval Climate Anomaly", MCA was considered as the tipping point that led to significant lake-level decline at Lake Prespa (Cvetkoska et al., 2014a and references therein). In fact, Prespa's decline of $\sim 20 \mathrm{~m}$ at the time of the MCA, as also evident in the position of the historic settlements around the lake (Sibinoviç, 1987), is a close analogue to the modelled lake-level decline of $20 \mathrm{~m}$ that can potentially increase the P load in Lake Ohrid by almost $30 \%$ (see Fig. 11 in Matzinger et al., 2006). However, the lack of meso-eutrophic species and low TOC, in combination with the high water depth at the DEEP site coring location and the sample resolution do not support enhanced nutrient levels and, by extension, significant influence from Lake Prespa. Moreover, the co-dominance of $C$. ocellata and $C$. minuscula between $1.5 \mathrm{ka}$ and present can be related to a combination of warm climate and/or anthropogenic influence at the DEEP site, as also shown from the diatom study of core Co1262 from the Lini site (Zhang et al., 2016).

\section{Ecosystems internal dynamics and interactions}

\subsection{Adaptive cycles: thresholds, regimes, resistance and resilience}

From the above interpretation and comparison between the lakes, shifts in the diatom communities, and by inference the lakes' response, are triggered by critical thresholds at differ- 
ent scales of intensity and by different external factors. As pointed out by Cvetkoska et al. (2015), while the diatom response in Lake Prespa is primarily driven by moisture availability, the multi-proxy approach in this study shows that regime shifts in Lake Ohrid are tipped by temperature thresholds, inducing changes in wind activity, light and nutrient availability.

Apart from the encountered differences, two adaptive cycles can be identified at orbital scale: "interglacial and interstadial" and "glacial" cycle. The glacial cycle of Lake Prespa is characterized by much lower productivity than the interglacial/interstadial cycle and dominated by facultative planktonic and benthic species (Cvetkoska et al., 2015). The lake experienced multiple regime shifts on sub-orbital timescale, resulting in low or high lake levels, and changes between (oligo-) meso- and eutrophic regimes.

Lake Ohrid's glacial cycle is mainly dominated by the hypolimnetic planktonic $C$. fottii and is characterized by a lower productivity than the interglacial/interstadial cycles (Fig. 2). Within these cycles, short-term regime shifts in the diatom communities occur at sub-orbital timescale, but the lake remained ultra- to oligotrophic. Based on the presented proxy data, there is no indication for lake-level changes throughout the entire studied period.

More importantly, all diatom data show that during the last 92.0 ka both lakes did not undergo catastrophic ecosystem collapses imprinted by loss of the diatom communities, and/or ecosystems functionality, such as happened at other ancient lakes during the LGM, like Baikal and Hövsgöl (Karabanov et al., 2004; Khursevich et al., 2006).

Assessing the capacity of both ecosystems to absorb disturbances and reorganize in order to retain their functional and structural characteristics implies that both lakes have different response mechanisms. The concept of the "ecosystems resilience" (Holling, 1973) is widely accepted, but also controversial because of its definition of mechanisms and components (Carpenter et al., 2001; Scheffer et al., 2001; Walker et al., 2004; Lake, 2013). Here, we consider the "resistance" and "resilience" as different components of the ecosystems response to disturbance; by interpreting the resistance in this case as the capacity of the ecosystem to absorb and withstand the disturbance and the resilience as the capacity to reorganize and/or restore or "recover" from the disturbance (Westman, 1978; Webster et al., 1983). As evident from the diatom and bio(geochemical) data, and the comparison of the lakes (Fig. 4), the amplitude of Lake Ohrid's response, appears smaller and in some cases shifting more gradually into the new regime, like for example at the MIS 5/4 transition (Figs. 2, 4).

This implies a high capacity of Lake Ohrid to absorb the disturbances and retain, and/or reorganize its structure, in order to maintain its functionality. Similarly, once pushed into a new regime, a tipping point of much higher intensity is required so the system can reorganize and/or restore a similar dynamic regime. In the DEEP site record, this pattern is ev- ident from the gradual, prolonged "recovery" periods after climate disturbances, as the gradual transition and muted response to the two-step deglaciation pattern of Termination I (cf. Lowe et al., 2008).

Relatively low intensity disturbances in Lake Prespa, however, are occasionally already sufficient to trigger highamplitude changes in lake levels and productivity (DCA Axes 1 and 2 in Fig. 4), emphasizing a lower lake capacity to absorb disturbance. An example is the abrupt shift from oligo-mesotrophic to eutrophic conditions during MIS $5 b$ (Fig. 4). Interestingly, the relatively short periods of "recovery" after these climate-induced disturbances, like for example the rapid lake-level increase after the LGM, demonstrates that Lake Prespa is a resilient ecosystem. These lakes' specific differences can be attributed to their different physical properties and hydrological balances.

\subsection{Lake ecosystem interactions}

Understanding the interactions between lakes Prespa and Ohrid requires assessment of several parameters which influence the dynamics of their hydrological connection through the karst system of Mt. Galičica: (i) Lake Prespa water balance, (ii) the P load and TP concentration in the lake, (iii) the underground outflow from Lake Prespa, and (iv) the P load from Lake Prespa to Lake Ohrid. Matzinger et al. (2006) assessed these parameters, demonstrating that currently about $20 \%$ of Lake Ohrid water inflow and $7 \%$ of the P load originate from Lake Prespa. However, a large part, $\sim 65 \%$, of the $\mathrm{P}$ load from Lake Prespa is retained in the karst aquifers. Lake Prespa is highly sensitive to water loss and a $5 \mathrm{~m}$ lakelevel decrease corresponds to a $\sim 25 \%$ loss of the total lake volume, with significantly increasing concentration of dissolved nutrients (Matzinger et al., 2006).

In order to understand the role of Lake Prespa as a possible driver of lake-level and/or nutrient shifts in Lake Ohrid over the past $92.0 \mathrm{ka}$, we explored the panarchy within the "sister lake system" by identifying possible cross-scale linkages between the adaptive cycles and regime changes of both lakes as lower-scale entities of the landscape dynamics.

From the comparison of the multi-proxy inferred lake levels and productivity of both lakes (see Ecosystem dynamics, Fig. 4), it is evident that the low lake-level and eutrophic conditions at Prespa during the interglacials, such as during MIS 5a and the MCA, do not counterpart with similar regimes at Lake Ohrid DEEP site. On the contrary, Lake Ohrid recharge was probably reduced during the glacial, when lake level at Prespa was low and discontinuous permafrost prevailed in the catchment (Belmecheri et al., 2009). Indeed, Lacey et al. (2014) already discussed the potential scenario for reduced water input from Prespa during the glacials resulting in lower lake water $\delta^{18} \mathrm{O}$. The palynological analyses of the last ca. $0.5 \mathrm{Ma}$ from the DEEP site sequence (Sadori et al., 2016) and pollen based reconstructed LGM temperatures (Peyron et al., 1998) support the 
existence of discontinuous permafrost and suggest that the karst aquifer system was not completely shut off during the glacials. Distinct water-level reductions are not evident in the DEEP site diatom record from the last ca. $92.0 \mathrm{ka}$, nor have been observed in the geochemistry and diatom data from the previous studies covering the last interglacial-glacial cycle (Wagner et al., 2009; Reed et al., 2010; Cvetkoska et al., 2015; Zhang et al., 2016).

As pointed by Matzinger et al. (2006) the P load to Lake Ohrid changes with decreasing Lake Prespa water level, but it highly depends on the following factors: (i) a smaller subaquatic outflow is reducing the $\mathrm{P}$ input, (ii) declining volumes of Lake Prespa lead to increase in $\mathrm{P}$ concentration in the lake and (iii) shorter hydraulic residence time of Lake Prespa decreases its $\mathrm{P}$ concentration. On glacial-interglacial scale, this would imply that potentially higher $\mathrm{P}$ supply to Ohrid due to lower lake level in Prespa is probably compensated by smaller subaquatic outflow.

On a Quaternary scale, it can be argued that climate disturbances leading to changes in lake level and trophic regimes in Lake Prespa were probably insufficient to affect Lake Ohrid's productivity. This decoupling results from the high resistance of Lake Ohrid, or at least the DEEP site, against the disturbances which could have been introduced from Lake Prespa. Moreover, the data show that from MIS 5b to present, Lake Ohrid did not undergo regime changes introduced by Lake Prespa and did not experience a phase of collapse, or release $(\Omega)$ as defined by Holling (1986).

\section{Conclusions}

From the presented data, it is evident that apart from the climatically triggered regime shifts, the lack of similar abrupt peaks in the lake levels and/or productivity in the sediment records of lakes Ohrid and Prespa, there is no clear indication for a direct link between the lakes' regime changes. While Lake Prespa shifted from shallow eutrophic to deep (oligo)mesotrophic regimes and vice versa, Lake Ohrid changed between ultra oligo- and oligotrophic, deep lake system over the last glacial-interglacial period.

In general, both lakes display different response mechanisms to external disturbances. While Lake Ohrid is more resistant to climate change, Lake Prespa is very sensitive, but a resilient ecosystem, and recovers in a relatively short time. Nonetheless, both lakes did not experience loss of the diatom communities and/or catastrophic ecosystem collapses.

The overall comparison provides sufficient evidence to disregard the theory of Prespa-dependent regime shifts in Ohrid, at least in its central and deepest parts. This may give future research on Lake Ohrid a more confident interpretation of the earlier parts of the DEEP site sediment sequence in terms of climate change.

\section{The Supplement related to this article is available online at doi:10.5194/bg-13-3147-2016-supplement.}

Acknowledgements. The SCOPSCO Lake Ohrid drilling campaign was funded by ICDP, the German Ministry of Higher Education and Research, the German Research Foundation, the University of Cologne, the British Geological Survey, the INGV and CNR (both Italy), and the governments of the Republics of Macedonia and Albania. Logistic support was provided by the Hydrobiological Institute in Ohrid. Drilling was carried out by Drilling, Observation and Sampling of the Earth's Continental Crust's (DOSECC) and using the Deep Lake Drilling System (DLDS). Special thanks are due to Beau Marshall and the drilling team. Ali Skinner and Martin Melles provided immense help and advice during logistic preparation and the drilling operation.

Aleksandra Cvetkoska would like to thank David Versluis, Keechy Akkerman and Jan van Tongeren for technical assistance. We thank Jane Reed and the Anonymous referee, for their comments and suggestions which helped us improve the manuscript. We also thank Jack Middelburg for editing the manuscript.

Edited by: J. Middelburg

\section{References}

Albrecht, C. and Wilke, T.: Ancient Lake Ohrid: biodiversity and evolution, Hydrobiologia, 615, 103-140, doi:10.1007/s10750008-9558-y, 2008.

Allen, C. R. and Holling, C. S.: Discontinuities in ecosystems and other complex systems, Columbia University Press, New York, 2008.

Allen, C. R., Gunderson, L., and Johnson, A. R.: The use of discontinuities and functional groups to assess relative resilience in complex systems, Ecosystems, 8, 958-66, doi:10.1007/s10021005-0147-x, 2005.

Allen, C. R., Angeler, D., Garmestani, A., Gunderson, L., and Holling, C. S.: Panarchy: Theory and Application, Ecosystems, 17, 578-589, doi:10.1007/s10021-013-9744-2, 2014.

Allen, H. L. and Ocevski, B. T.: Limnological studies in a large, deep, oligotrophic lake (Lake Ohrid, Yugoslavia): evaluation of nutrient availability and control of phytoplankton production through in situ radiobioassay procedures, Arch. Hydrobiol., 77, 1-21, 1976.

Anderson, N. J.: A whole-basin diatom accumulation rate for a small eutrophic lake in Northern Ireland and its paelaeoecological implications, J. Ecol., 77, 926-946, doi:10.2307/2260814, 1989.

Anovski, T., Jovanovski, N., and Arsov, Lj.: Rate determination of water leakage from Prespa Lake, in: International Symposium "Towards Integrated Conservation and Sustainable Development of Transboundary Macro and Micro Prespa Lakes”, 24-26 October 1997, Korca, Albania, 29-31, 1997. 
Anovski, T., Leontijadis, I., and Zoto, J.: Progress in study of Lake Prespa using nuclear and related techniques, IAEA Regional Project, RER/8/808, 6-22, 2001.

Aufgebauer, A., Panagiotopoulos, K., Wagner, B., Schaebitz, F., Viehberg, F., Vogel, H., Zanchetta, G., Sulpizio, R., Leng, M., and Damaschke, M.: Climate and environmental change in the Balkans over the last $17 \mathrm{ka}$ recorded in sediments from Lake Prespa (Albania/F.Y.R. of Macedonia/Greece), Quatern. Int., 274, 122-135, doi:10.1016/j.quaint.2012.02.015, 2012.

Bar-Matthews, M., Ayalon, A., Gilmour, M., Matthews, A., and Hawkesworth, C. J.: Sea-land oxygen isotopic relationships from planktonic foraminifera and speleothems in the Eastern Mediterranean region and their implication for paleorainfall during interglacial intervals, Geochim. Cosmochim. Ac., 67, 31813199, 2003.

Battarbee, R. W.: Diatom analysis, in: Handbook of Holocene palaeoecology and palaeohydrology, edited by: Berglund, B. E., Wiley and Sons, Chichester, Great Britain, 527-570, 1986.

Baumgarten, H., Wonik, T., Tanner, D. C., Francke, A., Wagner, B., Zanchetta, G., Sulpizio, R., Giaccio, B., and Nomade, S.: Age-depth model of the past $630 \mathrm{kyr}$ for Lake Ohrid (FYROM/Albania) based on cyclostratigraphic analysis of downhole gamma ray data, Biogeosciences, 12, 7453-7465, doi:10.5194/bg-12-7453-2015, 2015.

Belmecheri, S., Namiotko, T., Robert, C., von Grafenstein, U., and Danielopol, D. L.: Climate controlled ostracod preservation in Lake Ohrid (Albania, Macedonia), Palaeogeogr. Palaeocl., 277, 236-245, doi:10.1016/j.palaeo.2009.04.013, 2009.

Brennan, G. and Collins, S.: Growth responses of a green alga to multiple environmental drivers, Nature Climate Change, 5, 892897, doi:10.1038/nclimate2682, 2015.

Burnett, A., Soreghan, M., Scholz, C., and Brown, E.: Tropical East African climate change and its relation to global climate: A record from Lake Tanganyika, Tropical East Africa, over the past $90+$ kyr, Palaeogeogr. Palaeocl., 303, 155-167, doi:10.1016/j.palaeo.2010.02.011, 2011.

Carpenter, S., Walker, B., Anderies, J., and Abel, N.: From Metaphor to Measurement: Resilience of What to What?, Ecosystems, 4, 765-781, doi:10.1007/s10021-001-0045-9, 2001.

Cohen, A., Stone, J., Beuning, K., Park, L., Reinthal, P., Dettman, D., Scholz, C., Johnson, T., King, J., Talbot, M., Brown, E., and Ivory, S.: Ecological consequences of early Late Pleistocene megadroughts in tropical Africa, P. Natl. Acad. Sci. USA, 104, 16422-16427, doi:10.1073/pnas.0703873104, 2007.

Cvetkoska, A., Reed, J. M., and Levkov, Z.: Diatoms as indicators of environmental change in ancient Lake Ohrid during the last glacial-interglacial cycle (ca $140 \mathrm{ka}$ ), in: Diatom monographs, vol. 15, edited by: Witkowski, A., A.R.G. Gartner Verlag, Ruggell, Liechtenstein, 220 pp., 2012.

Cvetkoska, A., Levkov, Z., Reed, J. M., and Wagner, B.: Late Glacial to Holocene climate change and human impact in the Mediterranean: The last ca. $17 \mathrm{ka}$ diatom record of Lake Prespa (Macedonia/Albania/Greece), Paleogeogr. Paleocl., 406, 22-32, doi:10.1016/j.palaeo.2014.04.010, 2014a.

Cvetkoska, A., Hamilton, P. B., Ognjanova-Rumenova, N., and Levkov, Z.,: Observations of the genus Cyclotella (Kützing) Brébisson in ancient lakes Ohrid and Prespa and a description of two new species $C$. paraocellata spec. nov. and $C$. prespanen- sis spec. nov., Nova Hedwigia, 98, 313-340, doi:10.1127/00295035/2014/0154, 2014b.

Cvetkoska, A., Levkov, Z., Reed, J. M., Wagner, B., Panagiotopoulos, K., Leng, M., and Lacey, J.: Quaternary climate change and Heinrich events in the southern Balkans: Lake Prespa diatom palaeolimnology from the last interglacial to present, J. Paleolimnol., 53, 215-231, doi:10.1007/s10933-014-9821-3, 2015.

D’Addabbo, M., Sulpizio, R., Guidi, M., Capitani, G., Mantecca, P., and Zanchetta, G.: Ash leachates from some recent eruptions of Mount Etna (Italy) and Popocatépetl (Mexico) volcanoes and their impact on amphibian living freshwater organisms, Biogeosciences, 12, 7087-7106, doi:10.5194/bg-12-7087-2015, 2015.

Damaschke, M., Sulpizio, R., Zanchetta, G., Wagner, B., Böhm, A., Nowaczyk, N., Rethemeyer, J., and Hilgers, A.: Tephrostratigraphic studies on a sediment core from Lake Prespa in the Balkans, Clim. Past, 9, 267-287, doi:10.5194/cp-9-267-2013, 2013.

Delcourt, P. A. and Delcourt, H. R.: Prehistoric Native Americans and Ecological Change: Human Ecosystems in Eastern North America since the Pleistocene, Cambridge University Press, Cambridge, UK, 2004.

Edlund, M. B., Williams, R. M., and Soninkhishig, N.: The planktonic diatom diversity of ancient Lake Hövsgöl, Mongolia, Phycologia, 42, 232-260, 2003.

Föller, K., Stelbrink, B., Hauffe, T., Albrecht, C., and Wilke, T.: Constant diversification rates of endemic gastropods in ancient Lake Ohrid: ecosystem resilience likely buffers environmental fluctuations, Biogeosciences, 12, 7209-7222, doi:10.5194/bg12-7209-2015, 2015.

Francke, A., Wagner, B., Just, J., Leicher, N., Gromig, R., Baumgarten, H., Vogel, H., Lacey, J. H., Sadori, L., Wonik, T., Leng, M. J., Zanchetta, G., Sulpizio, R., and Giaccio, B.: Sedimentological processes and environmental variability at Lake Ohrid (Macedonia, Albania) between $637 \mathrm{ka}$ and the present, Biogeosciences, 13, 1179-1196, doi:10.5194/bg-13-1179-2016, 2016.

Grimm, E. C.: CONISS: a FORTRAN 77 program for stratigraphically constrained cluster analysis by the method of incremental sum of squares, Comput. Geosci., 13, 13-35, doi:10.1016/00983004(87)90022-7, 1987.

Holling, C. S.: Resilience and Stability of Ecological Systems, Annu. Rev. Ecol. Evol. Syst., 4, 1-23, doi:10.1146/annurev.es.04.110173.000245, 1973.

Holling, C. S.: The resilience of terrestrial ecosystems: local surprise and global change, in: Sustainable Development of the Biosphere, edited by: Clark, W. C. and Munn, R. E., Cambridge University Press, London, 292-317, 1986.

Holling, C. S.: Understanding the complexity of economic, ecological, and social systems, Ecosystems, 4, 390-405, doi:10.1007/s10021-001-0101-5, 2001.

Hollis, G. and Stevenson, A.: The physical basis of the Lake Mikri Prespa systems: geology, climate, hydrology and water quality, Hydrobiologia, 351, 1-19, doi:10.1023/A:1003067115862, 1997.

Holtvoeth, J., Rushworth, D., Copsey, H., Imeri, A., Cara, M., Vogel, H., Wagner, T., and Wolff, G. A.: Improved endmember characterisation of modern organic matter pools in the Ohrid Basin (Albania, Macedonia) and evaluation of new palaeoenvironmental proxies, Biogeosciences, 13, 795-816, doi:10.5194/bg-13-795-2016, 2016. 
Jongman, R. H. G., ter Braak, C. J. F., and van Tongeren, O. F. R.: Data analysis in community and landscape ecology, Cambridge University Press, Cambridge, 324 pp., 1995.

Jovanovska, E., Nakov, T., and Levkov, Z.: Observations of the genus Diploneis from Lake Ohrid, Macedonia, Diatom Res., 28, 237-262, doi:10.1080/0269249X.2013.797219, 2013.

Jovanovska, E., Cvetkoska, A., Hauffe, T., Levkov, Z., Wagner, B., Sulpizio, R., Francke, A., Albrecht, C., and Wilke, T.: Differential resilience of ancient sister lakes Ohrid and Prespa to environmental disturbances during the Late Pleistocene, Biogeosciences, 13, 1149-1161, doi:10.5194/bg-13-1149-2016, 2016.

Juggins, S.: C2 Version 1.5 User guide, Software for ecological and palaeoecological data analysis and visualization, Newcastle University, Newcastle upon Tyne, UK, 73 pp., 1991-2007.

Karabanov, E., Williams, D., Kuzmin, M., Sideleva, V., Khursevich, G., Prokopenko, A., Solotchina, E., Tkachenko, L., Fedenya, S., Kerber, E., Gvozdkov, A., Khlustov, O., Bezrukova, E., Letunova, P., and Krapivina, S.: Ecological collapse of Lake Baikal and Lake Hövsgöl ecosystems during the Last Glacial and consequences for aquatic species diversity, Palaeogeogr. Palaeocl., 209, 227-243, doi:10.1016/j.palaeo.2004.02.017, 2004.

Karaman, M.: Zoogeografski odnosi Prespanskog i Ohridskog jezera (Zoogeographical relationships of lakes Prespa and Ohrid), Izdanija, Zavod za ribarstvo na SR Makedonija, 4, 1-21, 1971 (in Serbian with German summary).

Khursevich, G. K.: Evolution of the extinct genera belonged to the family Stephanodiscaceae (Bacillariophyta) during the last eight million years in Lake Baikal, in: Advances in Phycological Studies, edited by: Ognjanova-Rumenova, N. and Manoylov, K., Pensoft Publishers, St. Kliment Ohridski University Press, Sofia, Moscow, 73-89, 2006.

Kilham, P., Kilham, S. S., and Hecky, R. E.: Hypothesized resource relationships among African planktonic diatoms, Limnol. Oceanogr., 31, 1169-1181, doi:10.4319/lo.1986.31.6.1169, 1986.

Krstić, S. S.: Environmental Changes in Lakes Catchments as a Trigger for Rapid Eutrophication - A Prespa Lake Case Study, in: Studies on Environmental and Applied Geomorphology, edited by: Piacentini, T., InTech, 63-118, doi:10.5772/27246, 2012.

Lacey, J., Francke, A., Leng, M., Vane, C., and Wagner, B.: A high-resolution Late Glacial to Holocene record of environmental change in the Mediterranean from Lake Ohrid (Macedonia/Albania), Int. J. Earth Sci., 104, 1623-1638, doi:10.1007/s00531-014-1033-6, 2014.

Lake, P.: Resistance, Resilience and Restoration, Ecological Management \& Restoration, 14, 20-24, doi:10.1111/emr.12016, 2013.

Leicher, N., Zanchetta, G., Sulpizio, R., Giaccio, B., Wagner, B., Nomade, S., Francke, A., and Del Carlo, P.: First tephrostratigraphic results of the DEEP site record from Lake Ohrid (Macedonia and Albania), Biogeosciences, 13, 2151-2178, doi:10.5194/bg-13-2151-2016, 2016.

Leng, M., Wagner, B., Boehm, A., Panagiotopoulos, K., Vane, C., Snelling, A., Haidon, C., Woodley, E., Vogel, H., Zanchetta, G., and Baneschi, I.: Understanding past climatic and hydrological variability in the Mediterranean from Lake Prespa sediment isotope and geochemical record over the Last Glacial cycle, Quaternary Sci. Rev., 66, 123-136, doi:10.1016/j.quascirev.2012.07.015, 2013.

Levkov, Z. and Williams, D. M.: Fifteen new diatom (Bacillariophyta) species from Lake Ohrid, Macedonia, Phytotaxa, 30, 141, doi:10.11646/phytotaxa.30.1.1, 2011.

Levkov, Z. and Williams, D. M.: Checklist of diatoms (Bacillariophyta) from Lake Ohrid and Lake Prespa (Macedonia) and their watersheds, Phytotaxa, 45, 1-76, 2012.

Levkov, Z., Krstic, S., Metzeltin, D., and Nakov, T.: Diatoms of Lakes Prespa and Ohrid: About 500 Taxa from Ancient Lake System, Iconographia Diatomologica, vol. 16, edited by: LangeBertalot, H., A.R.G. Gartner Verlag, Germany, 603 pp., 2007.

Lindhorst, K., Krastel, S., Reicherter, K., Stipp, M., Wagner, B., and Schwenk, T.: Sedimentary and tectonic evolution of Lake Ohrid (Macedonia/Albania), Basin Res., 27, 84-101, doi:10.1111/bre.12063, 2015.

Lisiecki, L. and Raymo, M.: A Pliocene-Pleistocene stack of 57 globally distributed benthic $\delta^{18} \mathrm{O}$ records, Paleoceanography, 20, PA1003, doi:10.1029/2004PA001071, 2005.

Lorenschat, J., Zhang, X., Anselmetti, F. S., Reed, J. M., Wessels, M., and Schwalb, A.: Recent anthropogenic impact in ancient Lake Ohrid (Macedonia/Albania): a palaeolimnological approach, J. Paleolimnol., 52, 139-154, doi:10.1007/s10933-0149783-5, 2014.

Lowe, J., Rasmussen, S., Björck, S., Hoek, W., Steffensen, J., Walker, M., and Yu, Z.: Synchronisation of palaeoenvironmental events in the North Atlantic region during the Last Termination: a revised protocol recommended by the INTIMATE group, Quaternary Sci. Rev., 27, 6-17, doi:10.1016/j.quascirev.2007.09.016, 2008.

Martrat, B., Grimalt, J. O., Lopez-Martinez, C., Cacho, I., Sierro, F. J., Flores, J. A., Zahn, R., Canals, M., Curtis, J. H., and Hodell, D. A.: Abrupt temperature changes in the Western Mediterranean over the past 250,000 years, Science, 306, 1762-1765, 2004.

Matzinger, A. and Schmid, M.: Eutrophication of ancient Lake Ohrid: Global warming amplifies detrimental effects of increased nutrient inputs, Limnol. Oceanogr., 52, 338-353, doi:10.4319/lo.2007.52.1.0338, 2007.

Matzinger, A., Jordanoski, M., Veljanoska-Sarafiloska, E., Sturm, M., Müller, B., and Wüest, A.: Is Lake Prespa Jeopardizing the Ecosystem of Ancient Lake Ohrid?, Hydrobiologia, 553, 89-109, doi:10.1007/s10750-005-6427-9, 2006.

McBride, S. and Edgar, R.: Janus cells unveiled: frustular morphometric variability in Gomphonema angustatum, Diatom Res., 13, 2, 293-310, doi:10.1080/0269249X.1998.9705452, 1998.

Meyer-Jacob, C., Vogel, H., Boxberg, F., Rosén, P., Weber, M. E., and Bindler, R.: Independent measurement of biogenic silica in sediments by FTIR spectroscopy and PLS regression, J. Paleolimnol., 52, 245-255, doi:10.1007/s10933-014-9791-5, 2014.

Panagiotopoulos, K., Aufgebauer, A., Schäbitz, F., and Wagner, B.: Vegetation and climate history of the Lake Prespa region since the Lateglacial, Quatern. Int., 293, 157-169, doi:10.1016/j.quaint.2012.05.048, 2013.

Panagiotopoulos, K., Böhm, A., Leng, M. J., Wagner, B., and Schäbitz, F.: Climate variability over the last $92 \mathrm{ka}$ in SW Balkans from analysis of sediments from Lake Prespa, Clim. Past, 10, 643-660, doi:10.5194/cp-10-643-2014, 2014. 
Pavlov, A., Levkov, Z., Williams, D. M., and Edlund, M. E.: Observations on Hippodonta (Bacillariophyceae) in selected ancient lakes, Phytotaxa, 90, 1-53, 2013.

Peyron, O., Guiot, J., Cheddadi, R., Tarasov, P., Reille, M., de Beaulieu, J.-L., Bottema, S., and Andrieu, V.: Climatic reconstruction in Europe for 18,000 yr B.P. from pollen data, Quaternary Res., 49, 183-196, doi:10.1006/qres.1997.1961, 1998.

Popovska, C. and Bonacci, O.: Basic data on the hydrology of Lakes Ohrid and Prespa, Hydrol. Process., 21, 658-664, doi:10.1002/hyp.6252, 2007.

$\mathrm{R}$ Core Team.: R: a language and environment for statistical computing, R Foundation for Statistical Computing, Vienna, Austria, available at: http://www.Rproject.org/, last access: June 2015, 2012.

Reed, J., Cvetkoska, A., Levkov, Z., Vogel, H., and Wagner, B.: The last glacial-interglacial cycle in Lake Ohrid (Macedonia/Albania): testing diatom response to climate, Biogeosciences, 3083-3094, doi:10.5194/bgd-7-4689-2010, 2010.

Ryves, D. B., Juggins, S., Fritz, S. C., and Battarbee, R. W.: Experimental diatom dissolution and the quantification of microfossil preservation in sediments, Palaeogeogr. Palaeocl., 172, 99-113, 2001.

Sadori, L., Koutsodendris, A., Panagiotopoulos, K., Masi, A., Bertini, A., Combourieu-Nebout, N., Francke, A., Kouli, K., Joannin, S., Mercuri, A. M., Peyron, O., Torri, P., Wagner, B., Zanchetta, G., Sinopoli, G., and Donders, T. H.: Pollen-based paleoenvironmental and paleoclimatic change at Lake Ohrid (south-eastern Europe) during the past $500 \mathrm{ka}$, Biogeosciences, 13, 1423-1437, doi:10.5194/bg-13-1423-2016, 2016.

Scheffer, M. and Carpenter, S. R.: Catastrophic regime shifts in ecosystems: linking theory to observation, Trends Ecol. Evol., 18, 648-656, doi:10.1016/j.tree.2003.09.002, 2003.

Scheffer, M., Carpenter, S., Foley, J., Folke, C., and Walker, B.: Catastrophic shifts in ecosystems, Nature, 413, 591-596, doi:10.1038/35098000, 2001.

Scholz, C. A., Cohen, A. S., Johnson, T. C., King, Talbot, M. R., and Brown, E. T.: Scientific drilling in the Great Rift Valley: The 2005 Lake Malawi Scientific Drilling Project - An overview of the past 145,000 years of climate variability in Southern Hemisphere East Africa, Palaeogeogr. Palaeocl., 303, 3-19, doi:10.1016/j.palaeo.2010.10.030, 2011.

Sibinoviç, M.: Ezera Prespansko i Ohridsko, The SRC \& Agency of Water Resources of R. of Macedonia, Skopje, 1967 (in Macedonian).

Stanković, S.: The Balkan Lake Ohrid and its living world, Monog. Biol. IX, Uitgeverij Dr. W. Junk, Den Haag, Netherlands, 357 pp., 1960.

Stoermer, E. F.: Polymorphism in Mastogloia, J. Phycol., 3, 73-77, doi:10.1111/j.1529-8817.1967.tb04633.x, 1967.

Stoermer, E. F., Emmert, G., and Schelske, C. L.: Morphological variation of Stephanodiscus niagarea Ehrenb. (Bacillariophyta) in a Lake Ontario sediment core, J. Paleolimnol., 2, 227-236, doi:10.1007/BF00202048, 1989.

Ter Braak, C. J. F. and Smilauer, P.: Canoco Reference Manual and User's Guide: Software for Ordination (Version 5.0), Ithaca, Microcomputer Power, NY, 2012.

Teubner, K: A light microscopical investigation and multivariate statistical analyses of heterovalvar cells of Cyclotella-species (Bacillariophyceae) from lakes of the
Berlin-Brandenburg region, Diatom Res., 10, 191-205, doi:10.1080/0269249X.1995.9705337, 1995.

Vogel, H., Rosén, P., Wagner, B., Melles, M., and Persson, P.: Fourier Transform Infrared Spectroscopy, a new costeffective tool for quantitative analysis of biogeochemical properties in long sediment records, J. Paleolimnol., 40, 689-702, doi:10.1007/s10933-008-9193-7, 2008.

Vogel, H., Zanchetta, G., Sulpizio, R., Wagner, B., and Nowaczyk, N.: A tephrostratigraphic record for the last glacial-interglacial cycle from Lake Ohrid, Albania and Macedonia, J. Quaternary Sci., 25, 320-338, doi:10.1002/jqs.1311, 2010a.

Vogel, H., Wagner, B., Zanchetta, G., Sulpizio, R., and Rosén, P.: A paleoclimate record with tephrochronological age control for the last glacial-interglacial cycle from Lake Ohrid, Albania and Macedonia, J. Paleolimnol., 44, 295-310, doi:10.1007/s10933009-9404-x, 2010b.

Vogel, H., Wessels, M., Albrecht, C., Stich, H.-B., and Wagner, B.: Spatial variability of recent sedimentation in Lake Ohrid (Albania/Macedonia), Biogeosciences, 7, 3333-3342, doi:10.5194/bg7-3333-2010, 2010c.

Wagner, B., Reicherter, K., Daut, G., Wessels, M., Matzinger, A., Schwalb, A., Spirkovski, Z., and Sanxhaku, M.: The potential of Lake Ohrid for long-term palaeoenvironmental reconstructions, Palaeogeogr. Palaeocl., 259, 341-356, doi:10.1016/j.palaeo.2007.10.015, 2008.

Wagner, B., Lotter, A. F., Nowaczyk, N., Reed, J. M., Schwalb, A., Sulpizio, R., Valsecchi, V., Wessels, M., and Zanchetta, G.: A 40.000-year record of environmental change from ancient Lake Ohrid (Albania and Macedonia), J. Paleolimnol., 41, 407-430, doi:10.1007/s10933-008-9234-2, 2009.

Wagner, B., Vogel, H., Zanchetta, G., and Sulpizio, R.: Environmental change within the Balkan region during the past ca. $50 \mathrm{ka}$ recorded in the sediments from lakes Prespa and Ohrid, Biogeosciences, 7, 3187-3198, doi:10.5194/bg-7-3187-2010, 2010.

Wagner, B., Aufgebauer, A., Vogel, H., Zanchetta, G., Sulpizio, R., and Damaschke, M.: Late Pleistocene and Holocene contourite drift in Lake Prespa (Albania/F.Y.R. of Macedonia/Greece), Quatern. Int., 274, 112-121, doi:10.1016/j.quaint.2012.02.016, 2012.

Wagner, B., Wilke, T., Krastel, S., Zanchetta, G., Sulpizio, R., Reicherter, K., Leng, M. J., Grazhdani, A., Trajanovski, S., Francke, A., Lindhorst, K., Levkov, Z., Cvetkoska, A., Reed, J. M., Zhang, X., Lacey, J. H., Wonik, T., Baumgarten, H., and Vogel, H.: The SCOPSCO drilling project recovers more than 1.2 million years of history from Lake Ohrid, Sci. Dril., 17, 19-29, doi:10.5194/sd-17-19-2014, 2014a.

Wagner, B., Leng, M. J., Wilke, T., Böhm, A., Panagiotopoulos, K., Vogel, H., Lacey, J. H., Zanchetta, G., and Sulpizio, R.: Distinct lake level lowstand in Lake Prespa (SE Europe) at the time of the 74 (75) ka Toba eruption, Clim. Past, 10, 261-267, doi:10.5194/cp-10-261-2014, 2014 b.

Walker, B., Holling, C. S., Carpenter, S. R., and Kinzig, A.: Resilience, adaptability and transformability in social-ecological systems, Ecol. Soc., available at: http://www.ecologyandsociety. org/vol9/iss2/art5/, last access: May 2015, 2004.

Watzin, M. C., Puka, V., and Naumoski, T. B.: Lake Ohrid and Its Watershed: State of the Environment Report, Lake Ohrid Conservation Project, Tirana, Albania and Ohrid, Macedonia, 2002. 
Webster, J. R., Gurtz, M. E., Haines, J. J., Meyer, J. L., Swank, W. T., Waide, J. B., and Wallace, J. B.: Stability of stream ecosystems, in: Stream Ecology: Application and Testing of General Ecological Theory, edited by: Barnes, J. R. and Minshall, G. W., Plenum Press, New York, 355-395, 1983.

Westman, W. E.: Measuring the inertia and resilience of ecosystems, BioScience, 28, 705-710, doi:10.2307/1307321, 1978.
Winder, M., Reuter, J. E., and Schladow, S. G.: Lake warming favors small-sized planktonic diatom species, P. Roy. Soc. B-Biol. Sci., 276, 427-435, doi:10.1098/rspb.2008.1200, 2009.

Zhang, X. S., Reed, J. M., Lacey, J. H., Francke, A., Leng, M. J., Levkov, Z., and Wagner, B.: Complexity of diatom response to Lateglacial and Holocene climate and environmental change in ancient, deep and oligotrophic Lake Ohrid (Macedonia and Albania), Biogeosciences, 13, 1351-1365, doi:10.5194/bg-13-13512016, 2016. 